\title{
Nanomedicine applications in orthopedic medicine: state of the art
}

\author{
This article was published in the following Dove Press journal: \\ International Journal of Nanomedicine \\ 28 September 2015 \\ Number of times this article has been viewed
}

\author{
Mozhdeh Mazaheri ${ }^{1, *}$ \\ Niloofar Eslahi ${ }^{1}, *$ \\ Farideh Ordikhani ${ }^{1, *}$ \\ Elnaz Tamjid ${ }^{2}$ \\ Abdolreza Simchi ${ }^{1,3}$ \\ 'Department of Materials Science \\ and Engineering, Sharif University \\ of Technology, ${ }^{2}$ Department of \\ Nanobiotechnology, Faculty of \\ Biological Sciences, Tarbiat Modares \\ University, ${ }^{3}$ Institute for Nanoscience \\ and Nanotechnology, Sharif University \\ of Technology, Tehran, Iran
}

*These authors contributed equally to this work

\begin{abstract}
The technological and clinical need for orthopedic replacement materials has led to significant advances in the field of nanomedicine, which embraces the breadth of nanotechnology from pharmacological agents and surface modification through to regulation and toxicology. A variety of nanostructures with unique chemical, physical, and biological properties have been engineered to improve the functionality and reliability of implantable medical devices. However, mimicking living bone tissue is still a challenge. The scope of this review is to highlight the most recent accomplishments and trends in designing nanomaterials and their applications in orthopedics with an outline on future directions and challenges.
\end{abstract}

Keywords: orthopedics, nanomedicine, tissue engineering, implantable materials, nanotoxicology

\section{Introduction}

Nanomedicine, the application of nanotechnology to medicine, aims to overcome problems related to diseases at nanoscale, where most of the biological molecules exist and operate. ${ }^{1}$ The response of host organisms at the protein and cellular level to nanomaterials is different from that observed for conventional materials. ${ }^{2}$ In orthopedic applications, there is a significant need and demand for the development of a bone substitute that is bioactive and exhibits material properties comparable with those of natural and healthy bone. ${ }^{3}$ For bone tissue engineering, nanostructured ceramics, polymers, metals, and composites have been receiving significant attention recently. ${ }^{4}$ Nanostructured materials enhance osteoblast functions (such as adhesion, proliferation, synthesis of bone-related proteins, and deposition of calcium-containing mineral) and promote adequate osteointegration due to increased surface area and roughness. ${ }^{5}$ Owing to the ability of nanomaterials to mimic the dimensions of constituent components of natural bone, ${ }^{3}$ they are promising candidates as the future and alternative orthopedic materials. Figure 1 summarizes the potential of nanomedicine in orthopedic applications. We believe that there are a plenty of room for development and implantation of nanomaterials in orthopedic medicine because nanofunctionalized scaffolds can provide structural support for the cells and regulate cell proliferation, differentiation, and migration. ${ }^{6}$ Many studies have shown that nanomaterials enable enhancement of osteointegration and promote healing of bone-related diseases. ${ }^{7}$ Wang et $\mathrm{al}^{8}$ have recently shown that nanostructured calcium phosphate scaffolds could support stem cell attachment/proliferation and induce osteogenic differentiation due to their chemical or crystallographic similarities to inorganic components of bone. Antimicrobial and drug-eluting coatings are other examples for the application of nanomaterials in orthopedic medicine. These coatings prevent infection risks of implants, which are the most common cause of reverse surgery. ${ }^{9}$ Meanwhile, potential pitfalls or undesirable
Correspondence: Abdolreza Simchi Department of Materials Science and Engineering, Sharif University of Technology, Azadi Avenue, PO Box I I365-9466, Tehran, Iran

Tel +982166165226

Fax +982166005717

Email simchi@sharif.edu 


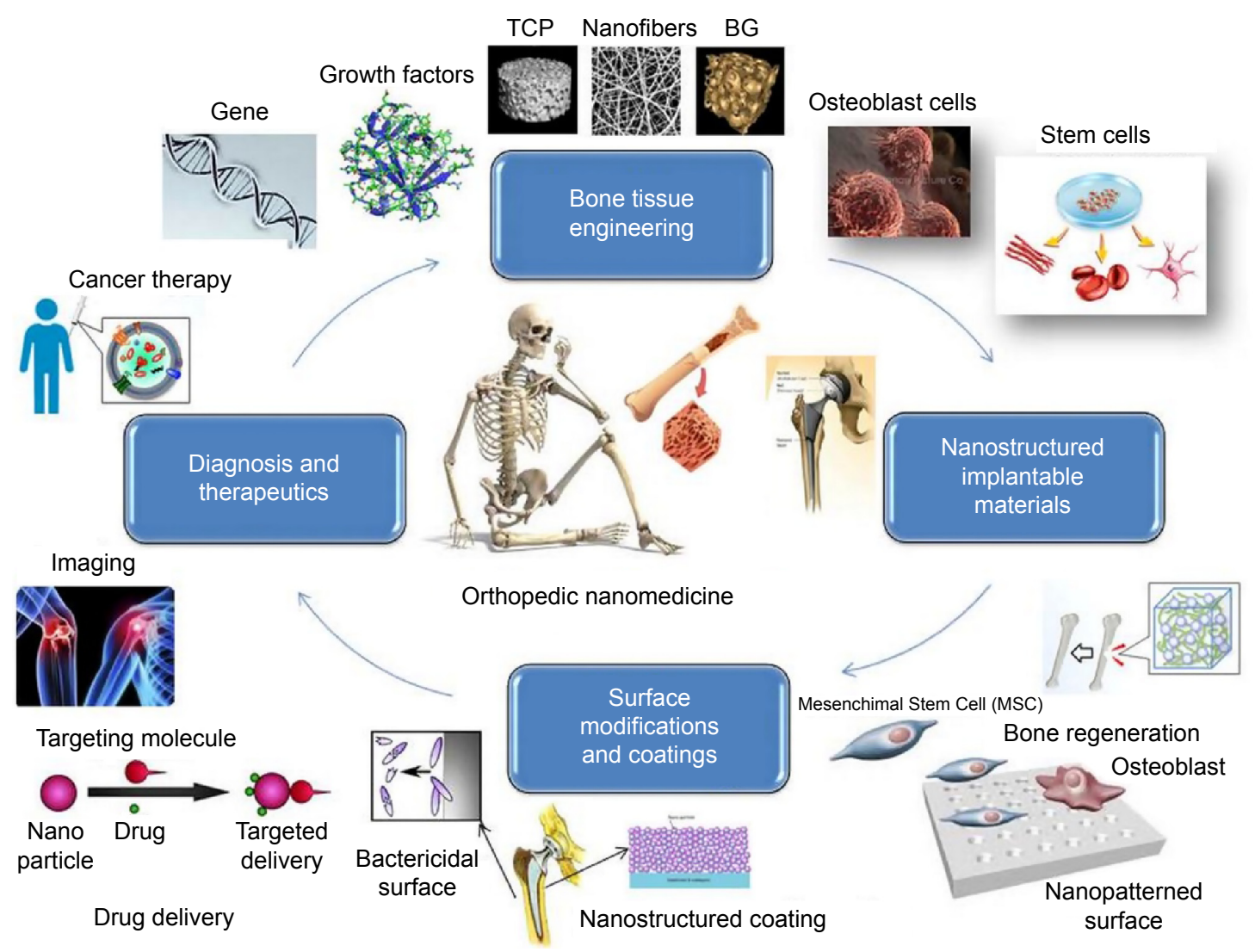

Figure I Scheme shows potential applications of nanomedicine in orthopedic medicine. Abbreviations: $\mathrm{BG}$, bioactive glass; TCP, tricalcium phosphate.

side effects associated with the use of nanomaterials should be considered. In this article, we review recent advances in utilizing nanomaterials for orthopedic medicine with a focus on implantable devices, functional coatings, surface modification techniques, diagnostics, and therapeutics. The potential risks of using nanomaterials are also presented.

\section{Nanomaterials for orthopedic applications}

The application of nanotechnology to bone substitutes is relatively a new frontier in orthopedic research. Nanotechnology offers novel materials that mimic the complex and hierarchical structure of the native bone tissue. ${ }^{10}$ Since natural tissues are nanometer in dimensions and cells directly interact with nanostructured extracellular matrices, the biomimetic features and excellent physiochemical properties of nanomaterials play a crucial role in stimulating cell growth as well as tissue regeneration. ${ }^{11}$ Some of the key characteristics that make nanomaterials attractive for orthopedic applications include high strength-to-weight ratio, wear/corrosion resistance, antimicrobial/drug release potentials, and tissue integration/ regeneration capabilities. ${ }^{12}$ This section overviews challenges in bone tissue engineering and elucidates how nanomaterials including ceramics, polymers, metals, and composites can be used to improve orthopedic implant by controlling their surface properties. Table 1 summarizes typical materials in orthopedic medicine including nanostructures.

\section{Challenges in bone tissue engineering and requirements}

The repair of large bone defects due to injury or disease is one of the major problems in orthopedic and maxillofacial surgery ${ }^{63}$ Bone is a vascular and highly specialized form of connective tissue composed of $10 \%-20 \%$ collagen, $60 \%-70 \%$ bone mineral (mainly hydroxyapatite [HA]), and $9 \%-20 \%$ water, by weight. ${ }^{64}$ Conventional clinical treatments for bone repair and regeneration include autologous and allogeneic transplantations which have several limitations and complications, such as donor site morbidity and immunogenic response. ${ }^{65}$ Tissue engineering emerged as a promising alternative for the reconstitution of lost or damaged organs and tissues, circumventing the problems associated with traditional transplants. ${ }^{66}$ Although attempts have resulted in the development of novel biomaterials that 


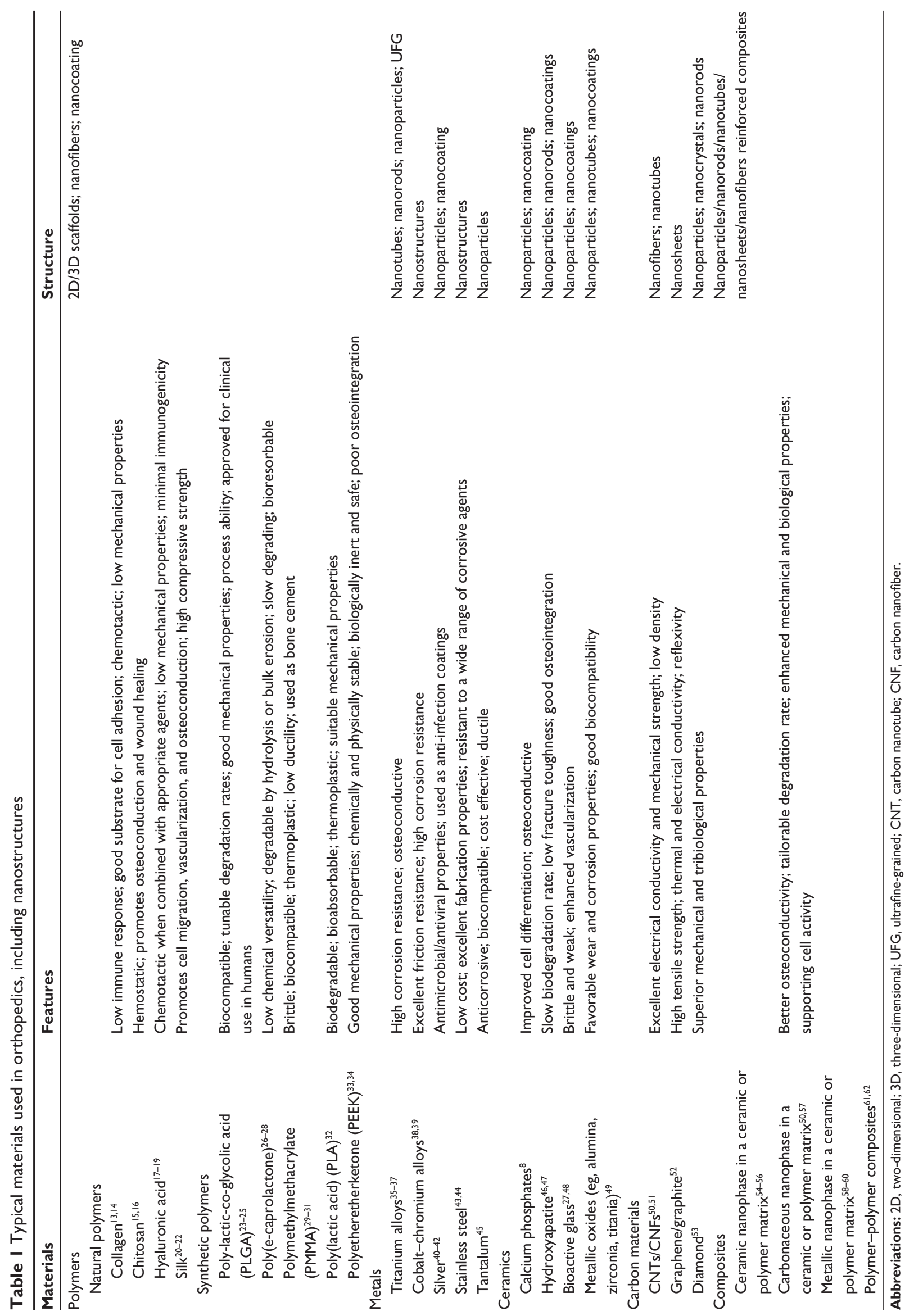


support the capacity of the body to regenerate bone and integrate with the surrounding bone tissue, ${ }^{67}$ more efforts are still required for the developed biomaterials to mimic living bone tissue. Specifically, these materials need to be biocompatible, biodegradable, osteoconductive, integrative, porous, and mechanically compatible with the native bone to fulfill the requirements of bone tissue reconstruction. ${ }^{63}$ Current challenges are related to engineering materials that can match both the mechanical and biological context of real bone tissue matrix and support the vascularization of large tissue constructs while restoring its physiological function. ${ }^{68-70}$ Novel biomimetic scaffolds should be emerged to recreate nanoscale topographical and biofactor cues using biofunctionalization strategies. ${ }^{71}$ Growth factors including bone morphogenetic proteins (BMP) as well as osteogenic/ stem cells could also be loaded into the biomaterials in order to stimulate bone growth, collagen synthesis, and fracture repair in vivo. ${ }^{72,73}$

\section{Implantable nanomaterials for orthopedics}

Typical implantable biomaterials to provide structural support as bone substitutes encompass stainless steel alloys, cobaltchrome alloys, titanium alloys, magnesium alloys, HA, alumina, zirconia, polymethylmethacrylate (PMMA), poly(lactic acid) (PLA), carbon fiber/polyetherether-ketone, and carbon fiber/ultra-high molecular weight polyethylene. ${ }^{60,74,75}$ With recent advances in nanotechnology, nanostructured materials have emerged as novel orthopedic implants with greater potential to provide osseointegration while having cellfavorable surface properties to efficiently stimulate new bone growth as compared to common materials. ${ }^{11}$ For instance, nanostructuring of metallic implantable devices enhances their mechanical properties and biocompatibility. ${ }^{36}$ Nowadays, bulk nanocrystalline $(\mathrm{NC} ;<100 \mathrm{~nm})$ and ultrafine-grained (UFG; 100-500 nm) metals including titanium (Ti) and their alloys can commercially be fabricated by severe plastic deformation (SPD) techniques ${ }^{76}$ and powder metallurgy $(\mathrm{P} / \mathrm{M})^{36}$ routes. Herein, a bulk metal or powder material is subjected to high plastic strains with complex stress state, leading to breaking the coarse grains down into nanoscale range. Nanostructured Ti implants produced by SPD are bioinert without a potential toxic or allergic effects of alloying elements (such as $\mathrm{Al}$ and $\mathrm{V})$ while having higher strength $(>1,000 \mathrm{MPa})$ than conventional ones. ${ }^{76}$ Very recently, Gain et al ${ }^{55}$ have shown that UFG/NC P/M Ti implants have a higher strength and better ductility than common $\mathrm{Ti}-6 \mathrm{Al}-4 \mathrm{~V}$ alloys and Ti parts processed by SPD. Estrin et al ${ }^{77}$ prepared UFG Ti
(170-200 nm) by equal channel angular pressing (ECAP) and compared the attachment of human bone marrow-derived mesenchymal stem cells (hMSCs) to the surface with a coarsegrained (CG) Ti specimen $(4.5 \mu \mathrm{m})$. It was demonstrated that the attachment and spreading of hMSCs in the initial stages (up to 24 hours) of culture was enhanced. Wang et al ${ }^{78}$ fabricated TiN-coated UFG Ti $(\sim 130 \mathrm{~nm})$ by high-pressure torsion technique. The developed material showed a great potential as implants, owing to its high strength, reasonable ductility, good fatigue life, excellent abrasion resistance, and a nontoxic ion release. Park et $\mathrm{al}^{79}$ investigated in vitro biocompatibility of UFG Ti produced by ECAP using MC3T3-E1 cells as compared to the commercially pure (CP) $\mathrm{Ti}$ and $\mathrm{Ti}-6 \mathrm{Al}-4 \mathrm{~V}$ alloy. The specimens were grit-blasted with HA particles to produce microrough surfaces. The UFG material exhibited enhanced biological response including cell spreading, cell attachment, cell viability, Alkaline phosphatase (ALP) activity, osteopontin and osteocalcin mRNA levels in cells grown, and mineralization nodule formation. Another orthopedic material is elemental selenium, which has potential anticancer chemistry. Unlike titanium, selenium is an essential trace element in the human body. Selenium is important because mammalian selenoproteins play a role in antioxidant defense systems, thyroid hormone metabolism, and redox control of cell reactions. ${ }^{80}$ In vitro research has shown the inhibitory effects of selenium on the growth of many cancerous cell lines. ${ }^{81}$ Perla and Webster ${ }^{80}$ have demonstrated the positive effect of selenium on osteoblast growth. Tran and Webster ${ }^{82}$ created nanostructured roughness on selenium compacts for anticancer orthopedic applications and showed that healthy bone cell adhesion increased with greater nanometer selenium roughness. However, this mode of selenium addition can result in poor, unsuitable mechanical properties of the implant since selenium, being a metalloid, does not have sufficient mechanical strength. Moreover, considering that selenium is toxic at high doses, the stability and control over its release would be an extremely desirable attribute. ${ }^{81}$ As an alternative strategy for using selenium as an anticancer orthopedic material, Tran et $\mathrm{al}^{81}$ have fabricated a nanoselenium-coated titanium for improving orthopedic applications. They have demonstrated the potential of selenium nanoclusters as a chemopreventive Ti orthopedic material coating that can also promote healthy bone cell functions.

Besides, bioceramics are the most demanding materials for orthopedic applications, although their inherent brittleness prevented their use in some applications. Nanophased ceramics could offer advantages of improved fracture toughness with an ability to promote biofunctionality. ${ }^{83}$ Recent advances 
include nanostructuring of various bioceramics including zirconia, titania, alumina, calcium phosphates, bioactive glass (BG), and HA. ${ }^{84}$ Studies have shown that nanostructuring yields higher mechanical strength with improved ductility and toughness as the finer grains hinder dislocation slip and cause crack blunting. ${ }^{85}$ Additionally, processing of nanoceramics at lower temperatures becomes feasible as the sintering activity is higher. ${ }^{84}$ Meanwhile, restricting of grain growth upon high-temperature processing is challenging. Nanophased bioceramics also exhibit better functionality with cells both in vitro and in vivo. Zhou et $\mathrm{al}^{46}$ have reported that NC HA provides a better substrate for cell viability and proliferation of rabbit MSCs compared to CG HA in vitro. Bosco et $\mathrm{al}^{47}$ have shown an improved apoptosis of osteoclast-like cells of bone-like HA nanocrystals functionalized with alendronate in vitro. Nanostructured BG scaffolds are capable of guiding bone formation in a rabbit ulnar critical-sized-defect model with successful crack bridging. ${ }^{86}$

Synthetic and natural polymers are also excellent candidates for bone/cartilage tissue engineering applications. Natural polymers such as collagen, fibrin, chitosan (CS), hyaluronic acid, and alginate are biocompatible and biologically active and hence promote cell adhesion and growth. ${ }^{87}$ These natural materials have the advantage over synthetic ones in being similar to materials in the body and have potential to be used as implant surface scaffolds. ${ }^{88,89}$ Levengood and Zhang ${ }^{15}$ highlighted recent advances in the development of CS-based scaffolds with enhanced bone regeneration capability. Mandal et $\mathrm{al}^{90}$ fabricated silk-fiber-reinforced composite matrices with a high compressive strength $(\sim 13 \mathrm{MPa}$ hydrated state) for bone engineering applications. Schiavi et $\mathrm{al}^{14}$ introduced a new generation of collagen nanofiber implant functionalized with growth factor BMP-7 nanoreservoirs and equipped with human MSC microtissues for bone regenerative nanomedicine. Many different polymer nanofibers have also been investigated for bone tissue replacements. ${ }^{29}$ These nanoporous or nanofibrous polymer matrices can be fabricated via electrospinning, phase separation, particulate leaching, chemical etching, and 3D printing techniques. ${ }^{11}$ Xin et $\mathrm{al}^{23}$ prepared electrospun PLGA nanofibrous scaffolds and studied the viability, growth, and differentiation of hMSCs as well as their osteogenic and chondrogenic derivatives. Results indicated that hMSCs continuously differentiated into chondrogenic cells and osteogenic cells after 2-week incubation in PLGA nanofibers. Park et $\mathrm{al}^{24}$ reported enhanced chondrocyte functions on nanostructured 3D PLGA scaffolds.

In general, nanoceramics and nanopolymers are mostly used as coating constituent materials for orthopedics or can be combined with other biomaterials to form nanocomposites that are suitable for implant applications. As mentioned earlier, bone is a true nanocomposite, so that nanocomposites are more beneficial than other nanostructured materials. Common nanocomposites for bone tissue regeneration consist of a ceramic nanophase in a ceramic matrix, a carbonaceous nanophase in a ceramic or polymer matrix, or a ceramic nanophase in a polymer matrix..$^{50,54}$ Gain et $\mathrm{a}^{55}$ fabricated porous $\mathrm{HA} / \mathrm{ZrO}_{2}$ nanocomposites by $\mathrm{P} / \mathrm{M}$ technique and showed that the nanocomposites exhibited better compressive strength and elastic modulus than that of porous monolithic HA due to the reinforcing effect of $\mathrm{ZrO}_{2}$ nanoparticles (NPs). Ceramic-polymer nanocomposites have also attracted particular attention for use as bone tissue regeneration materials because of their excellent combination of bioactivity and osteoconductivity of ceramics, and the flexibility and shape controllability of polymers. ${ }^{91}$ Very recently, Hickey et $\mathrm{al}^{56}$ have prepared PLLA-based nanocomposites reinforced with $\mathrm{HA}$ and $\mathrm{MgO}$ NPs. Their results indicate that $\mathrm{MgO}$ NPs significantly enhance osteoblast adhesion and proliferation on HA-PLLA nanocomposites while maintaining mechanical properties suitable for cancellous bone applications. Sadat-Shojai et $\mathrm{al}^{92}$ synthesized 3D HA/gelatin hydrogel nanocomposites with enhanced stiffness that may be useful for treatment of cancellous bone defects or low load-bearing orthopedic applications. The encapsulation of MC3T3-E1 cells into the nanocomposites revealed that the whole process of composite formation was compatible with the bone cells. New alternative reinforcing materials are carbon nanomaterials. Due to their ultra-high mechanical strength over most other materials, carbon nanostructures (include carbon nanotubes, carbon nanofibers, graphene, nanodiamond (ND), and so forth) are effective additives to improve the mechanical properties of orthopedic materials. ${ }^{50}$ Baradaran et $\mathrm{al}^{93}$ fabricated reduced graphene oxide (rGO)reinforced HA (nanotube) composites using a hydrothermal process. They showed improved elastic modulus and fracture toughness of the sintered samples with increasing of the rGO content. Enhanced osteoblast adhesion and proliferation were also reported. Wu et $\mathrm{al}^{94}$ studied the biomimetic growth behavior of HA on CNFs functionalized with carboxylic groups and evaluated the structure and fracture strength of the resulting composites. Due to the strong interfacial bonding between HA and CNFs, improved mechanical strength with a potential of interfacial bonding of HA to host tissues was attained. In another study, ${ }^{57}$ multiwalled carbon nanotubes (MWCNTs) and HA nanorods were incorporated into polypropylene to form biocomposites for bone replacements. 
The mechanical tests and 3-(4,5-Dimethylthiazol-2-Y1)-2,5Diphenyltetrazolium Bromide (MTT) assay demonstrated that the mechanical properties including stiffness, tensile strength, and impact toughness were improved without a major side effect on the biocompatibility.

\section{Surface modifications}

The surface properties, surface chemistry, topography, and roughness of implantable materials influence their cell response and the absorption of biomolecules that regulate cell attachment and migration. ${ }^{95}$ Various methods have been employed for the surface modification of implants to enhance their integration capacity with osseous tissue. ${ }^{96}$ So far, techniques such as electrochemical processing, hydrothermal treatment, sandblasting, sol-gel, and chemical etching have been employed..$^{97-99}$ In many attempts, formation of a dense or porous $\mathrm{TiO}_{2}$ film on the surface of Ti implants have been examined. ${ }^{98,100}$ Much work has also been performed on the preparation of $\mathrm{TiO}_{2}$ nanotubes in order to increase the surface roughness and to improve biological performance of implants. ${ }^{41,101}$ Metals (eg, Ag), ${ }^{41}$ inorganic materials (like $\mathrm{Ca}, \mathrm{P}),{ }^{102}$ or biomolecules (such as antibiotics) ${ }^{103}$ may be incorporated in the surface layer to provide bactericidal capacity, increased ALP activity, and improved osseointegration. Surface modifications of Ti implants via different methods indicate that the rougher surfaces exhibit better early cell adhesive and proliferative abilities. ${ }^{97}$ Rosales-Leal et al ${ }^{104}$ investigated MG-63 cell culture on CP Ti with different surface treatments. It has been found that cell attachment is improved on rougher surfaces with irregular morphologies and more collagen are produced when cell grow on. Koller et $\mathrm{al}^{96}$ have reported that BG abrasion can increase the roughness of CP Ti surfaces, leading to a bioactive and osteopromotive implant material. Although biological properties may be improved by surface roughening of implants, contact corrosion-fatigue can lead to surface instability and development of microcracks on the contacting surface. ${ }^{38,104}$ Ryu and Shrotriya ${ }^{38}$ showed that surface roughness of medical grade CoCrMo alloy exponentially accelerates the localized damage on the implant surfaces by contact corrosion-fatigue. Therefore, although the surface roughness has a beneficial effect on the implant biocompatibility, it may decrease the implant life time.

\section{Surface nanostructuring}

Microscale topography enhances biological events with indirect effect on cellular activity. ${ }^{98}$ More direct outcomes may be obtained by nanoscale surface features because nanotopography can guide various molecular and biological processes at the implant/tissue interfaces while the provided large surface areas afford more binding sites to cell membrane receptors. ${ }^{35,101}$ Surface nanoarchitectures improve the in vivo and in vitro biocompatibility of implants. ${ }^{105}$ Figure 2 shows the effect of surface nanostructuring on the properties of CP Ti. Xia et $\mathrm{al}^{35}$ showed that the nanostructured topologies of Ti implants improve the proliferation, differentiation (Figure 2A-D), and development of the osteoblastic phenotype and increase the bone-implant interfacial strength. It is well documented that preparation of porous $\mathrm{TiO}_{2}$ film or $\mathrm{TiO}_{2}$ nanotubes improves the cell viability due to the higher surface energy, a larger number of particle-binding sites, and the topology mechanism. ${ }^{35,106}$ Cell attachment and proliferation are also improved. Furthermore, $\mathrm{TiO}_{2}$ nanotube films can provide antimicrobial activity particularly under ultraviolet (UV) radiation and/or in the presence of silver ions (Figure 2E and F). ${ }^{41}$ Salou et $\mathrm{l}^{107}$ studied the osseointegration of microstructured and nanostructured implants in rabbit femurs. They have shown that both the bone-to-implant contact and bone growth values are slightly higher for the nanostructured surface and it is better integrated into the bone. Experiments on the rabbit tibia using nanogrooved $\mathrm{Ti}$ implants indicated the dependency of bone response to the distribution of nanogrooves up to 8 weeks. ${ }^{108}$

\section{Nanostructured coatings}

Surface functionalization of orthopedic implants by nanostructured coatings and nanocomposites is an alternative way to affect their integration to bone while tailoring their biological responses. Many studies have been devoted to the preparation and characterizations of nanoceramics, nanopolymers, nanocomposites, and carbon nanomaterials on implantable materials. Safonov et $\mathrm{l}^{109}$ have shown that nanostructured $\mathrm{Al}_{2} \mathrm{O}_{3}$ coating on the surface of implantable metals such as Ti alloys and stainless steel improves in vivo and in vitro biocompatibility due to hydrophilic nature of the coated surface. Deposition of glycidyl methacrylate (GMA) nanolayer on the surface of Ti improves cellular attachment. ${ }^{110}$ Various polymer-based nanocomposites such as $\mathrm{PCL} / \mathrm{TiO}_{2},{ }^{26}$ $\mathrm{PCL} / \mathrm{n}-\mathrm{BG},{ }^{27} \mathrm{CS} / \mathrm{BG},{ }^{111}$ polymer/HA,${ }^{56}$ and polymer/calcium phosphate $^{8}$ have been examined and shown to possess improved bioactivity, enhanced mechanical properties, and better osteoconductivity. Many studies have also focused on utilizing carbon nanostructures as orthopedic implants coatings. ${ }^{50}$ Prodana et al ${ }^{106}$ developed a complex ceramic coating on Ti plates with $\mathrm{TiO}_{2}$ nanotubes, HA NPs, and functionalized MWCNTs. The complex coating showed a better biological adhesion and osteoblasts response. Ahmed al ${ }^{112}$ prepared CS/MWCNTs $/ \mathrm{CaCO}_{3}$ nanocomposites on the surface of $\mathrm{Ti}-6 \mathrm{Al}-4 \mathrm{~V}$ alloy and reported improved bioactivity 
A

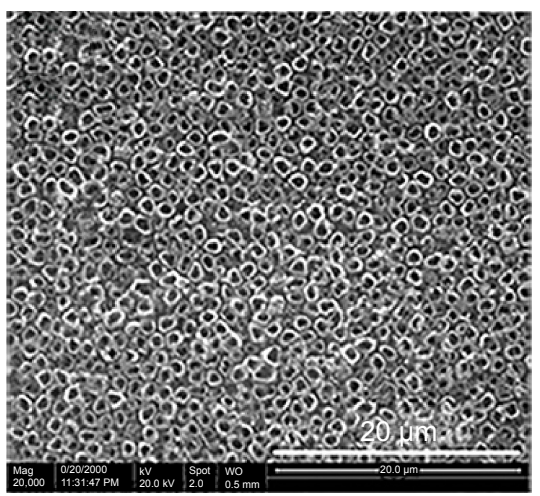

C

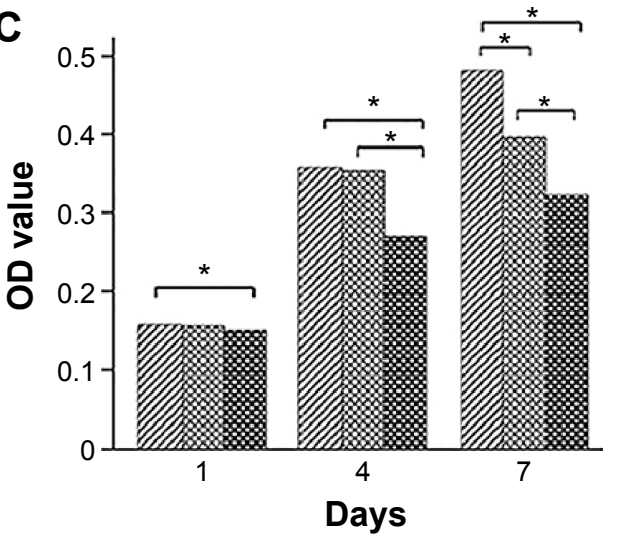

B

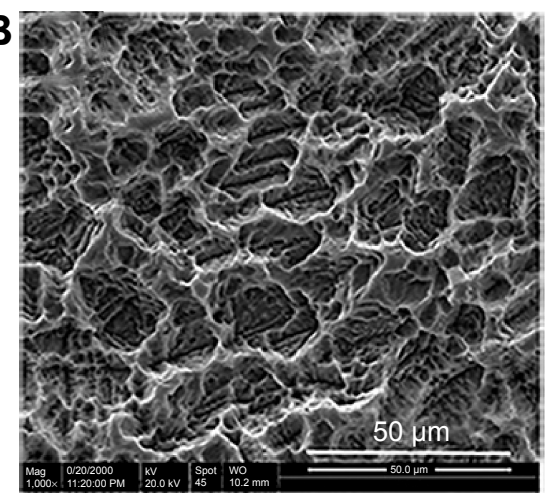

D

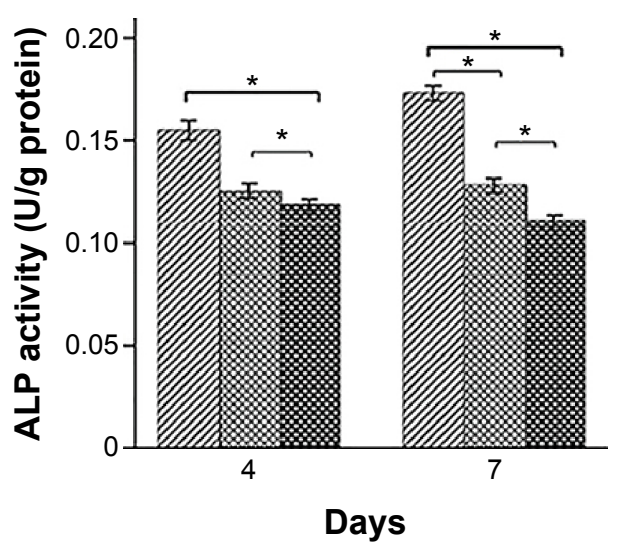

nanoTi microTi flatTi

E

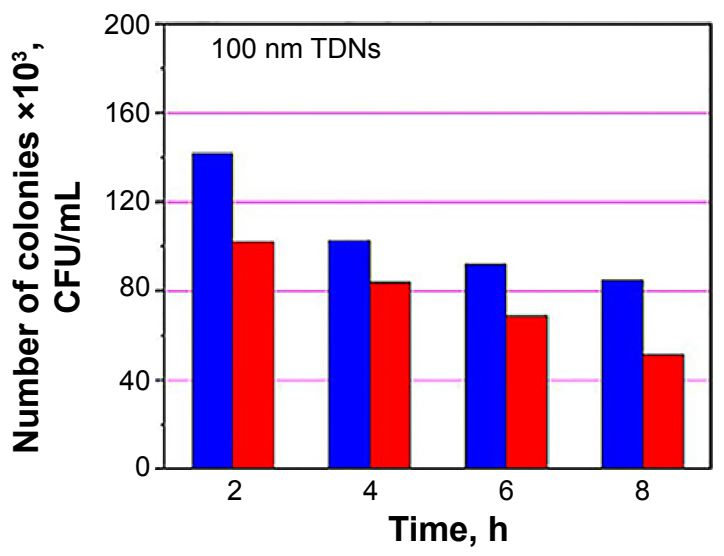

No UV $\square$ With UV
$\mathbf{F}$

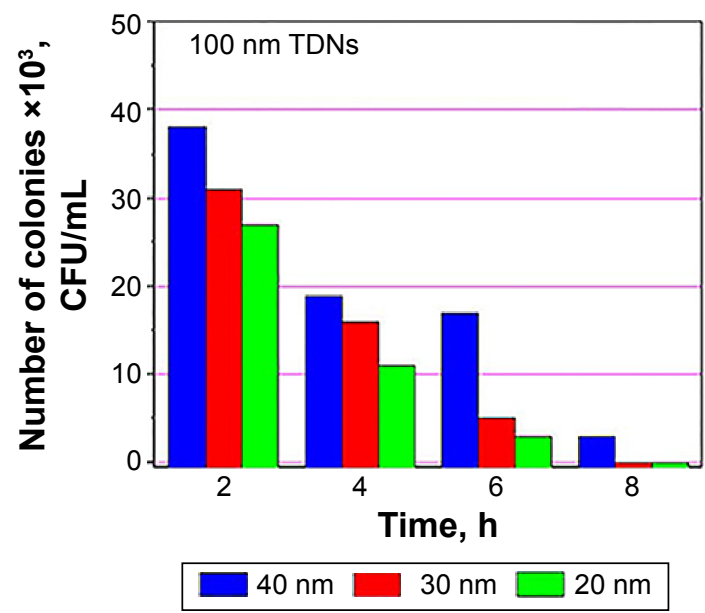

Figure 2 Effects of surface nanostructuring on the cell viability, differentiation, and bactericidal capacity of CP Ti.

Notes: (A, B) SEM images of $\mathrm{TiO}_{2}$ nanotube layer and microporous titanium, respectively. (C, D) The nanostructuring effect on the MG-63 cell proliferation and ALP activity. Reproduced with permission of Dove Medical Press, from Xia L, Feng B, Wang P, et al. In vitro and in vivo studies of surface-structured implants for bone formation. Int J Nanomedicine. 2012;7:4873; permission conveyed through Copyright Clearance Center, Inc. ${ }^{35}$ Antibacterial activity of $\mathrm{TiO}_{2}$ nanotubes. Figure $2 \mathrm{C} * \mathrm{P}<0.05$, $\mathrm{n}=9$; Figure $2 \mathrm{D}$. $* P<0.05, n=7$. (E) under UV radiation and (F) in the presence of silver NPs of different sizes. Copyright (C 20 I4. John Wiley \& Sons, Inc. Reproduced from Esfandiari N, Simchi A, Bagheri R. Size tuning of Ag-decorated $\mathrm{TiO}_{2}$ nanotube arrays for improved bactericidal capacity of orthopedic implants. J Biomed Mater Res A. 20I4; I02(8):2625-2635.41

Abbreviations: CP, commercially pure; SEM, scanning electron microscope; ALP, alkaline phosphatase; UV, ultraviolet; NPs, nanoparticles; h, hours; TDN, titanium dioxide nanotubes.

and corrosion resistance of the orthopedic implant. Ordikhani et $\mathrm{al}^{113}$ fabricated novel GO/CS nanocomposite coatings on the surface of Ti foils by electrophoretic deposition (EPD) technique (Figure 3A). In vitro viability assay by human osteosarcoma cells (MG-63) demonstrated that the nanocomposite films were highly biocompatible up to $30 \mathrm{wt} \%$ GO (Figure 3B). The GO/CS films also supported the initial attachment, proliferation, and growth of the cells (Figure 3C). Mansoorianfar et $\mathrm{al}^{53}$ incorporated NDs and BG NPs in alginate films by EPD technique to prepare functional 
coatings on Ti implants (Figure 3D). In vitro bioactivity assessment in simulated body fluid (SBF) and MTT assay using MG-63 and L929 cells exhibited enhanced biocompatibility and bioactivity of the composite films (Figure 3E and F). Table 2 summarizes the surface modification methods for titanium and its alloys as the most widely used implantable materials in orthopedic medicine.

\section{Orthopedic infections, diagnosis, and therapeutics \\ Drug-eluting and antibacterial coatings}

Postoperation infections of Ti implants including bacterial adhesion and biofilm formation remain the most common and serious complications in orthopedic surgery. ${ }^{40}$ A simple and promising approach to reduce the risk of these infections would be local administration of antibacterial agents through implants coatings. Recent studies have demonstrated the potential of drug-eluting CS-based coatings to prevent implant-associated infections. ${ }^{111,116}$ Microbial examinations against Gram-positive Staphylococcus aureus exhibited a diminished bacterial behavior without impairing cell attachment and proliferation (Figure $3 \mathrm{G}$ ). Results also showed that embedding of GO in the CS matrix affects the drug releasing profile with a longer release potential (Figure $3 \mathrm{H}$ ). The results determine that $\mathrm{GO}$ controls the release rate but reduces osteogenesis. ${ }^{113}$ Patel et al ${ }^{48}$ have developed drug-eluting composite coatings of $\mathrm{CS} / \mathrm{BG}$ NPs containing ampicillin. The drug was eluted from the coatings continuously over 10-11 weeks, confirming long-term drug delivering capacity. Antibacterial tests using agar diffusion assay against Streptococcus mutants also approved the positive effect of released ampicillin. Radin and Ducheyne ${ }^{117}$ used silica sol-gel technology to obtain thin antibacterial nanostructure coatings on the metallic substrates. Mattioli-Belmonte et $\mathrm{al}^{118}$ developed a ciprofloxacin-loaded CS NP-based coating on Ti substrates. This antibacterial coating was able to inhibit the growth of two nosocomial $S$. aureus strains in vitro without impairing the MG-63 viability, adhesion, and gene expression after
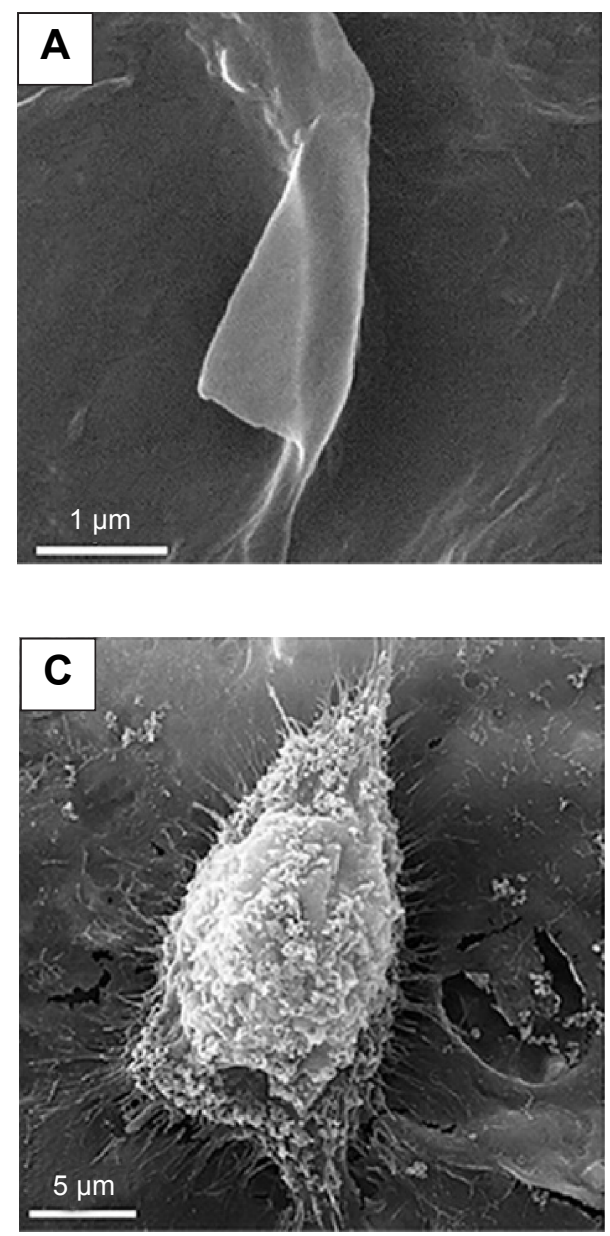

B
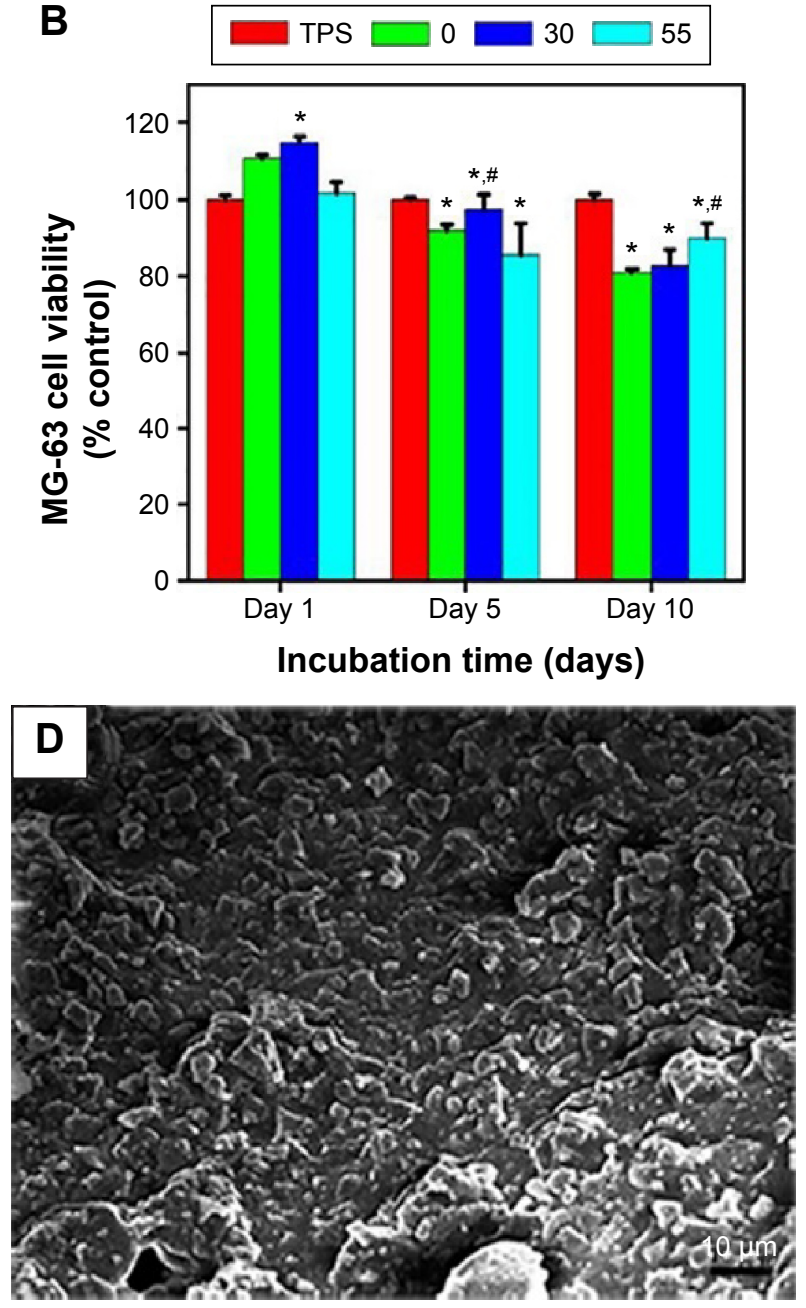

Figure 3 (Continued) 


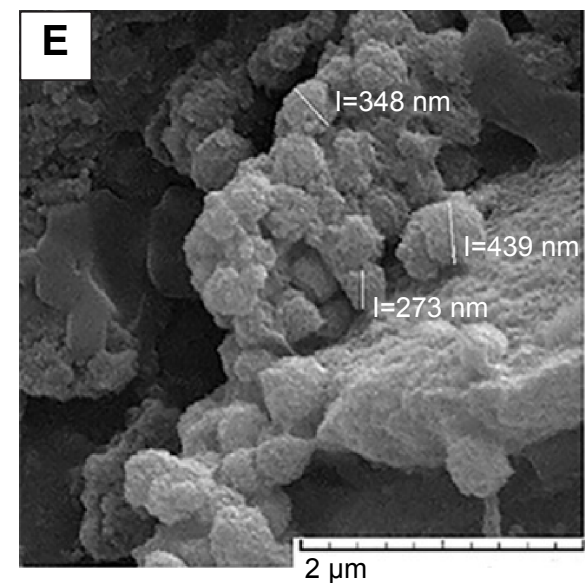

G

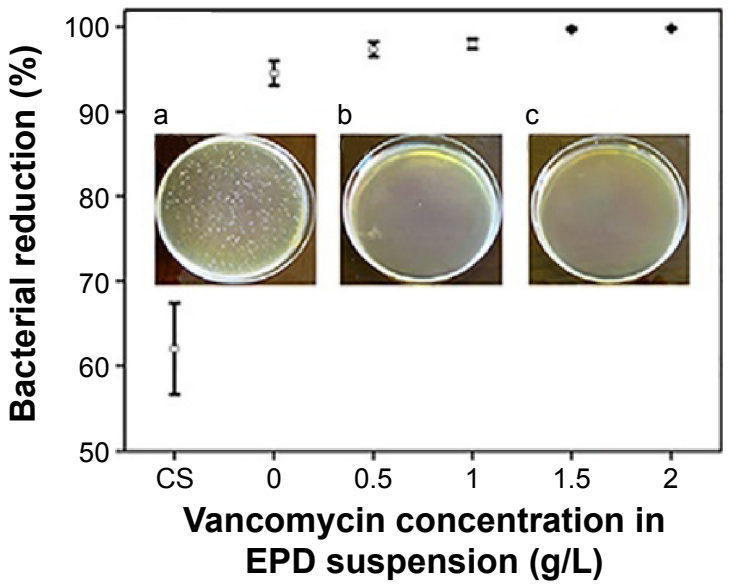

$\mathbf{F}$

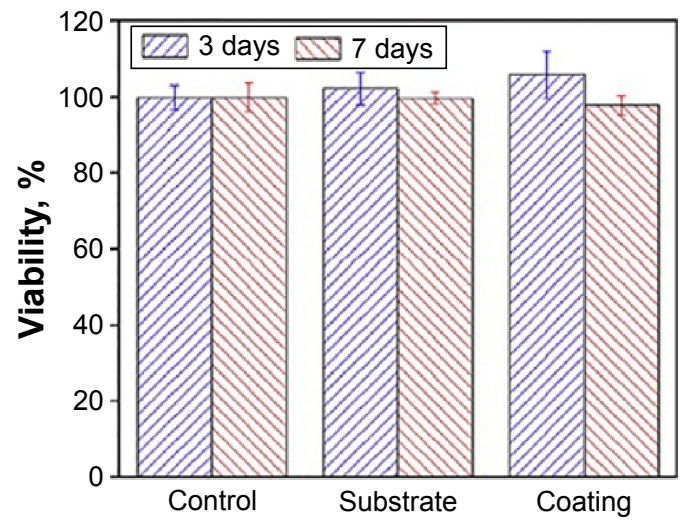

H

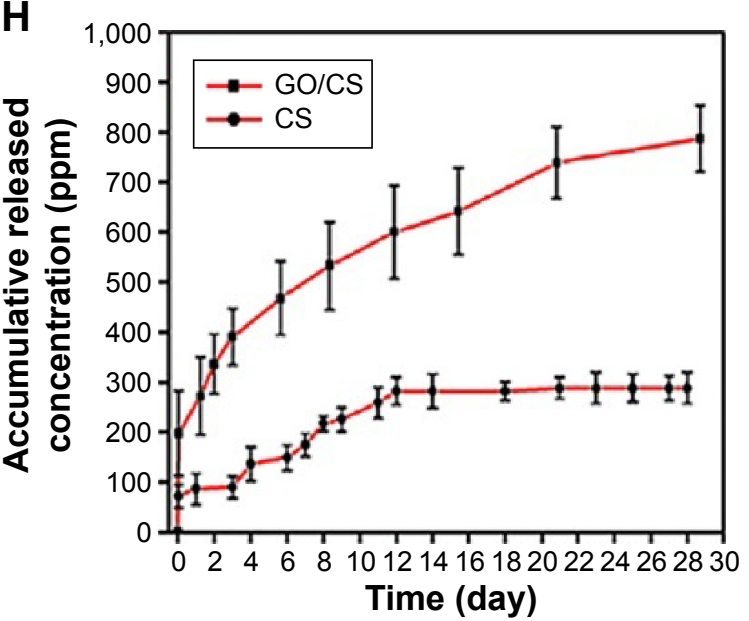

Figure 3 Effect of carbon nanostructures on the performance of electrodeposited polysaccharide coatings on Ti foils.

Notes: (A) SEM image of CS/GO (30 wt\%) coating."13 (B) MTT viability and (C) SEM morphology of MG-63 cells cultured on the surface of the CS/GO coating. (D) A SEM image of alginate/BG/ND film. Copyright @ 2013. Elsevier B.V. Reproduced from Mansoorianfar M, Shokrgozag MA, Mehrjoo M, Tamjid E, Simchi A. Nanodiamonds for surface engineering of orthopedic implants: enhanced biocompatibility in human osteosarcoma cell culture. Diam Relat Mater. 2013;40(0): 107-I I4. ${ }^{53}$ (E) Formation of apatite phases on the surface of the alginate coating after 28 days of incubation in the SBF and (F) its MG-63 cell viability response. (G) The antibacterial performance of the CS/GO coating containing vancomycin against Staphylococcus aureus. Insets: plate counting images showing S. aureus bacteria colonies after I 20 min incubation for the CS-30GO film containing (a) 0 , (b) 0.5 and (c) I g/I antibiotics. (H) Cumulative drug release of the CS/GO (30 wt\%) coating. Copyright (C) 20I5. Elsevier B.V. Reproduced from Ordikhani F, Ramezani Farani M, et al. Physicochemical and biological properties of electrodeposited graphene oxide/chitosan films with drug-eluting capacity. Carbon. 2015;84(0):91-102. ${ }^{13}$ *Denotes significant difference between TPS and EPD coatings $(P<0.05)$. "Denotes significant difference between $C S$ and composite coatings $(P<0.05)$.

Abbreviations: SEM, scanning electron microscope; CS, chitosan; GO, graphene oxide; BG, bioactive glass; ND, nanodiamond; SBF, simulated body fluid; TPS, tissue culture polystyrene; EPD, electrophoretic deposition; MTT, 3-(4,5-Dimethylthiazol-2-YI)-2,5-Diphenyltetrazolium Bromide.

Table 2 Surface modification methods for titanium and its alloys implants

\begin{tabular}{|c|c|c|}
\hline Surface modification method & Modified layer & Objectives \\
\hline Hydrothermal treatment ${ }^{100}$ & $\mathrm{TiO}_{2}$ film with different surface morphologies & $\begin{array}{l}\text { Improving the biological performance of implants through } \\
\text { enhanced bioactivity and osteoconductivity }\end{array}$ \\
\hline Sol-gel $\left.\right|^{114}$ & $\begin{array}{l}\text { Nanometer-scale films such as titania, } \\
\text { zirconia, and calcium phosphate }\end{array}$ & $\begin{array}{l}\text { Surface nanostructuring to improve biocompatibility and } \\
\text { bioactivity }\end{array}$ \\
\hline Chemical etching ${ }^{107}$ & $\begin{array}{l}\text { Nanometer-sized and micrometer-sized } \\
\text { surfaces }\end{array}$ & $\begin{array}{l}\text { Better attachment of osteoblastic cells along with improved } \\
\text { protein adsorption and osseointegration }\end{array}$ \\
\hline \multicolumn{3}{|l|}{ Physical methods } \\
\hline Machine grinding ${ }^{97}$ & Micrometer-rough and nanometer-rough & Creating surface topography for greater osseous contact \\
\hline Abrasive blasting ${ }^{96}$ & Ti surfaces & with improved mechanical interlocking \\
\hline $\begin{array}{l}\text { Sandblasting } \\
\text { Electrochemical processing } \\
\text { 41,97 }\end{array}$ & Nanoscale surfaces such as $\mathrm{TiO}_{2}$ nanotubes & $\begin{array}{l}\text { Improving the viability, attachment, and proliferation of cells; } \\
\text { increasing binding sites }\end{array}$ \\
\hline \multicolumn{3}{|l|}{ Nanostructured coatings } \\
\hline $\begin{array}{l}\text { Nanoceramics }^{53} \\
\text { Nanopolymers } \\
\text { Nanocomposites } \\
\text { N13 }\end{array}$ & $\begin{array}{l}\text { Thin film coatings such as } \mathrm{Al}_{2} \mathrm{O}_{3}, \mathrm{HA} \text {, calcium } \\
\text { phosphate, } \mathrm{CS} / \mathrm{GO} \text {, and } \mathrm{ND}\end{array}$ & $\begin{array}{l}\text { Improving in vivo and in vitro biocompatibility, bioactivity, } \\
\text { and bactericidal capacity }\end{array}$ \\
\hline
\end{tabular}

Abbreviations: HA, hydroxyapatite; CS, chitosan; GO, graphene oxide; ND, nanodiamond. 
several days. In another study, $\mathrm{TiO}_{2}$ nanotubes were used as cefuroxime carriers to prevent periprosthetic infections. ${ }^{119}$ Silver NPs have also been used as antibacterial agents in many studies. ${ }^{40-42,60}$ Recently, composite orthopedic coatings with antibacterial capability containing $\mathrm{CS} / \mathrm{BG} / \mathrm{Ag}$ NPs have been fabricated by employing a single-step EPD process. ${ }^{60}$ Studying of the structural and preliminary in vitro bactericidal and cellular properties showed that the composite coatings containing $342 \mu \mathrm{g}$ of Ag NPs were cytotoxic on MG-63 cells. Liu et al ${ }^{58}$ prepared a silver incorporated HA nanocomposite coating on implant surface and showed a significant enhancement in the antibacterial property in vitro. Zhao et $\mathrm{al}^{40}$ fabricated $\mathrm{TiO}_{2}$ nanotubes incorporated with Ag NPs on Ti implants. The bactericidal potential of the coating up to 30 days was shown. Anyway, the cytotoxicity of silver-loaded coatings is a great concern that can be reduced by controlling the $\mathrm{Ag}$ release rate. Esfandiari et $\mathrm{al}^{41}$ prepared $\mathrm{Ag}$-decorated $\mathrm{TiO}_{2}$ nanotubes with different sizes by a combined electrochemical and UV-assisted reduction method. They showed synergetic effect of $\mathrm{Ag} \mathrm{NPs}$ and $\mathrm{TiO}_{2}$ nanotubes on the bactericidal activity. The highest antibacterial activity of the coating was obtained for $\mathrm{TiO}_{2}$ nanotubes with opening diameter of $\sim 100 \mathrm{~nm}$ and silver NPs of $20 \mathrm{~nm}$. Yan et al ${ }^{59}$ synthesized HA films containing $\mathrm{Ag}^{+}$ions via electrochemical deposition on anodized Ti. In vitro examinations revealed that a HA coating containing $2.03 \mathrm{wt} \% \mathrm{Ag}$ had significant antibacterial and osteogenic properties.

\section{Diagnosis}

Another important issue in orthopedic therapies is detection of the healing sites by versatile tools in order to effectively detect bone-related diseases such as osteoporosis, Paget's disease, and renal osteodystrophy in the earliest stage and monitor orthopedic therapies. ${ }^{120}$ Implantable wireless biosensors have recently been developed for this purpose. ${ }^{121}$ Particularly, CNTs have been found of great potential for the fabrication of bone sensors ${ }^{51,122}$ due to their excellent electrical conductivity and mechanical strength as well as unique chemical-biological properties. The high electrical conductivity of CNTs promotes bone growth as bone regenerates under electrical conduction. Supronowicz et al ${ }^{123}$ reported a $46 \%$ increase in osteoblast proliferation as a result of adding MWCNTs into nanocomposites of PLA, and more than $300 \%$ rise in calcium production when an alternating current was applied to the substrate in vitro.

It is noteworthy that for such sensor design, cell responses transduce and transmit a variety of chemical and physical signals to produce specific substances and proteins within specific tissues and organs. Sirinrath and Thomas ${ }^{124}$ showed the redox of proteins could be enhanced on MWCNTs grown from an anodized nanotubular Ti electrode in order to sense bone growth, promote osteoblast proliferation, and differentiation after 21 days.

Another idea to monitor the bone turnover is detecting bone-related degradation products. A label-free electrochemical impedance spectroscopy immunosensor for detecting C-terminal teleopeptides from Type-1 collagen was developed by Yun et al. ${ }^{120,125}$ Such sensing methods are based on the principal idea that the cycle of bone remodeling consists of three consecutive phases: preexisting bone resorption by osteoclasts, a reversal phase that is characterized by mononuclear cells on the bone surface, and new bone formation by osteoblasts to fill in the cavities after resorption. These types of sensors can also be prepared on gold electrode but recent advances suggest utilizing CNT electrodes to enhance sensitivity due to improved electrical conductivity. For instance, CNT-TiN nanocomposites, composed of $12 \%$ CNTs by volume, showed a $45 \%$ increased electrical conductivity over TiN materials. ${ }^{126}$

Meanwhile, coupling drug delivery to implantable wireless sensors enables on-command diffusion-controlled drug delivery systems by using radio frequency, as a new approach in the orthopedic field. ${ }^{121}$ Taking advantage of nanotechnology, the upcoming future sensors can sense new bone formation, and if that is not happening, release drugs to promote new bone growth.

Stem cell therapies by hMSCs have exceptional regenerative potential and thus are promising candidates for bone regeneration and fracture healing. ${ }^{127,128}$ To monitor these processes, hMSCs have been labeled with diverse NPs such as quantum dots (QDs), fluorescence-labeled mesoporous silica NPs, gold NPs, and superparamagnetic iron oxide (SPIO) NPs. ${ }^{7}$ The fluorescent labeling of osteoblast cells using HA grown with nucleating seed of hydrophilic $\mathrm{CdSe} /$ ZnS QDs allows real-time observation of cell under confocal microscope. A study performed on MC3T3-E1 osteoblast cells showed that the cells could engulf HA with surfacetailored QDs showing fluorescent spots in the cytoplasm, while HA and QDs NPs were not engulfed. Interestingly, the fluorescence was only displayed in the cytoplasm of MC3T3-E1 osteoblast cells. ${ }^{129}$ Gold NPs have recently been investigated as contrast agents for micro-CT applications ${ }^{130,131}$ and advanced X-ray imaging technologies. ${ }^{132}$ Since Au has a higher absorption coefficient than Iodine and experiences less interference with bones and tissues, Au NPs improved contrast at lower doses while prolonging the imaging time. ${ }^{132}$ 
The SPIO NPs are also promising materials as contrast agents for MRI. Nevertheless, it should be noted that bone represents a formidable target organ, which poses a particular challenge with regard to cell labeling (due to its high mineralization grade); hence, making the visualization of labeled cells in MRI difficult. ${ }^{7}$ In a very recent study, the incorporation of a multimodal contrast agent based on HA nanocrystals within a PCL nanofibrous scaffold by electrospinning have been reported. This preliminary study was performed to eventually exploit the MR contrast imaging capability of nanofibrous scaffolds for real-time imaging of the changes in the tissue engineered construct. ${ }^{133}$ In a clinical trial performed on osteoblasts, SPIO NPs bounded to RGD receptors enabled stimulation of cells over a 3-week period. Following cyclical magnetic stimulation, labeled cells demonstrated upregulation of osteopontin and increased osteo-related protein production. These results indicate that culture of SPIONs with osteoblasts does not inhibit osteogenic behavior. Furthermore, SPIONs can be bound to selected membrane receptors and then subjected to oscillating magnetic fields via a magnetic force bioreactor in order to stimulate tagged receptors and provide mechanotransduction through the cell membrane. ${ }^{128}$

Similar attempts are being struggled for decreasing orthopedic implant infection and inflammation. As mentioned in the previous section, implant-associated infections are a serious health threat for patients, and their clinical management is expensive. Diagnosis of these infections is hampered by intracellular bacteria, formation of biofilms, and aseptic and posttraumatic changes. There is a clinical niche for improved diagnostic tools to uncover pathogenic forms of infections. Taking the advantages of NPs as contrast agents in CT and MRI imaging, nanotechnology can be an indispensable tool for infection diagnostic and eradication. Nuclear medicine using radiolabeled infection tracers is also a promising method for implant-associated infection diagnostic in clinics. Development of multiplexed imaging modalities together with identification of specific infection probes is progressing rapidly. ${ }^{134}$

Biological properties such as temperature and $\mathrm{pH}$ values at the border of the implant are key parameters that can be utilized for the characterization of the implant-bone interface infections. ${ }^{135}$ Gou et al ${ }^{136}$ developed a solid-state sensor based on oxidized single-walled carbon nanotubes functionalized with poly(1-aminoanthracene). By attaching to a passively powered radio frequency identification tag, they could transmit $\mathrm{pH}$ data through simulated skin. This device had a Nernstian response over a wide $\mathrm{pH}$ range
(2-12) and retained sensitivity over 120 days. It is therefore expected that new achievements in diagnostic imaging will significantly decrease the risk of late and falsely diagnosed implant-associated infections.

\section{Cancer therapy}

Skeletal complications resulting from bone cancer are an important health care problem. Osteosarcoma is the most common primary tumor of bone and considered to be the third most common malignancy in children and adolescents. ${ }^{137}$ Bone is the most common site of cancer metastasis and is particularly important in breast and prostate cancers because these diseases have a high prevalence of bone metastases. ${ }^{85}$ Bone metastases are mainly treated through surgery, radiotherapy, systemic chemotherapy, bisphosphonates, and radioisotopes. ${ }^{138}$ Recent advances have led to the development of multifunctional bionanomaterials that can target a bone tumor and deliver therapeutic drugs or genes. ${ }^{139}$ Various composite materials with different content of magnetite are used in order to induce hyperthermia. ${ }^{140,141}$ Andronescu et $\mathrm{al}^{13}$ developed a magnetite-enriched collagen/HA composite material as a bone graft material and also hyperthermia generator for bone cancer therapy. Hu et $\mathrm{al}^{141}$ prepared $3 \mathrm{D}$ nanomagnetite/CS rod, which could be useful for local hyperthermia in bone tumors. In another study, Murakami et al ${ }^{142}$ developed a magnetite/HA composite that facilitates direct bonding to bones through $\mathrm{HA}$ and generation of heat from magnetite (exposed to AC magnetic field) for hyperthermia therapies of cancer in bones. This composite had micro-sized pores of approximately $400 \mu \mathrm{m}$ and submicron-sized pores of approximately $0.2 \mu \mathrm{m}$ in size. They showed that magnetite aggregates were strongly trapped in the cages of rod-shaped HA particles at 30 mass $\%$ or less concentrations.

\section{Nanotoxicology}

By rapidly emerging science of nanotechnology and the development of new products in a wide range of applications, concerns have been raised regarding potential risks of nanomaterials on human health and environment that may result from exposure during their life cycle. ${ }^{143}$ Nanotoxicology, the science of engineered nanostructures that deals with the health threats or adverse effects on living organisms, has attracted a lot of attention recently. ${ }^{144}$ In practice, the diversity of engineered nanomaterials and their unlimited potential applications have posed major challenges for safety assessment. The analytical methods to detect and quantify concentrations of nanoscale materials in the environment and human body are still under development as well. ${ }^{145}$ Research on humans and animals indicates that 
some NPs are able to enter the body, and then translocate into different organs via the circulatory and lymphatic systems. ${ }^{150}$ Toxic responses to NPs generated from the degradation of implanted nanomaterials, via wear debris from artificial joints with nanofeatures, and heavy metals (iron, nickel, and cobalt catalysts) remaining in CNTs, have recently been reported. ${ }^{11,146}$ Even though nanophase materials have increased wear fatigue properties, debris may form from articulating components of nanostructured orthopedic implants when subjected to physiological loading properties. ${ }^{147}$ Potential adverse effects may range from inflammation, exacerbation of asthma and metal fume fever to fibrosis, chronic inflammatory lung diseases, and carcinogenesis. ${ }^{148}$ For instance, silica NPs have been shown to have a low toxicity in vivo when administered in moderate doses due to oxidative stress. Lung and embryonic toxicity has also been observed for CNTs. ${ }^{149}$ It should be noted that very little is known about the underlying toxicity mechanisms responsible for the possible toxic actions of nanomaterials. ${ }^{150}$ Production of increased reactive oxygen species is considered as the major cause of toxicity in nanoscale materials. ${ }^{148}$ It has been shown that the tendency for toxicity increases with decreasing particles size, even when the same material is inert in bulkier form, such as carbon and Ti dioxide. ${ }^{151}$ Therefore, the interactions between nanomaterials and living organisms as well as the biological effects of these materials should be exclusively studied. Particularly, the relationship between nanomaterial characteristics (size, shape, surface area, etc) and their toxic responses should be illustrated. ${ }^{152}$ Besides technological advancement that expands the nanomedicine market, ${ }^{153,154}$ we believe that much more in vivo evaluations, toxicological surveys, and clinical trials are needed before nanomaterials can be widely commercialized for orthopedic applications.

\section{Conclusion and future remarks}

Preliminary investigations support the potential of nanobiomaterials in orthopedic applications; however, advancements are still necessary to achieve clinical use. The goal is to fabricate bioactive scaffolds designed for bone regeneration that will temporarily substitute for natural tissues while interacting with their surroundings, respond to environmental changes, and actively direct cellular events for faster bone formation, reduced healing time, and rapid recovery to function. Future work will likely develop enhanced design methodologies to take advantage of nanomaterials and new fabrication technology. It is critical to understand molecular mechanisms of cell-nanobiomaterial interactions. Besides, validating the biosafety of nanomaterials and minimizing their impacts should be taken into consideration seriously.

\section{Disclosure}

The authors report no conflict of interest in this work.

\section{References}

1. Wang M, Thanou M. Targeting nanoparticles to cancer. Pharmacol Res. 2010;62(2):90-99.

2. Liu H, Webster TJ. Nanomedicine for implants: a review of studies and necessary experimental tools. Biomaterials. 2007;28(2):354-369.

3. Li X, Wang L, Fan Y, Feng Q, Cui F-Z, Watari F. Nanostructured scaffolds for bone tissue engineering. J Biomed Mater Res A. 2013;101A(8): 2424-2435.

4. McMahon RE, Wang L, Skoracki R, Mathur AB. Development of nanomaterials for bone repair and regeneration. $J$ Biomed Mater Res B Appl Biomater. 2012;101B(2):387-397.

5. Tran N, Webster TJ. Nanotechnology for bone materials. Wiley Interdiscip Rev Nanomed Nanobiotechnol. 2009;1(3):336-351.

6. McMahon RE, Wang L, Skoracki R, Mathur AB. Development of nanomaterials for bone repair and regeneration. $J$ Biomed Mater Res B Appl Biomater. 2013;101(2):387-397.

7. Tautzenberger A, Kovtun A, Ignatius A. Nanoparticles and their potential for application in bone. Int J Nanomedicine. 2012;7:4545-4557.

8. Wang P, Zhao L, Liu J, Weir MD, Zhou X, Xu HH. Bone tissue engineering via nanostructured calcium phosphate biomaterials and stem cells. Bone Res. 2014;(2) Article 14017.

9. Simchi A, Tamjid E, Pishbin F, Boccaccini AR. Recent progress in inorganic and composite coatings with bactericidal capability for orthopaedic applications. Nanomedicine. 2011;7(1):22-39.

10. Bose S, Vahabzadeh S, Bandyopadhyay A. Bone tissue engineering using 3D printing. Mater Today. 2013;16(12):496-504.

11. Zhang L, Webster TJ. Nanotechnology and nanomaterials: promises for improved tissue regeneration. Nano Today. 2009;4(1):66-80.

12. Shirwaiker RA, Samberg ME, Cohen PH, Wysk RA, MonteiroRiviere NA. Nanomaterials and synergistic low-intensity direct current (LIDC) stimulation technology for orthopedic implantable medical devices. Wiley Interdiscip Rev Nanomed Nanobiotechnol. 2013;5(3): 191-204.

13. Andronescu E, Ficai M, Voicu G, Ficai D, Maganu M, Ficai A. Synthesis and characterization of collagen/hydroxyapatite: magnetite composite material for bone cancer treatment. J Mater Sci Mater Med. 2010; 21(7):2237-2242.

14. Schiavi J, Keller L, Morand D-N, et al. Active implant combining human stem cell microtissues and growth factors for bone-regenerative nanomedicine. Nanomedicine. 2015;10(5):753-763.

15. Levengood SKL, Zhang M. Chitosan-based scaffolds for bone tissue engineering. J Mater Chem B. 2014;2(21):3161-3184.

16. Venkatesan J, Kim S-K. Chitosan composites for bone tissue engineering - an overview. Mar Drugs. 2010;8(8):2252-2266.

17. Kim J, Kim IS, Cho TH, et al. Bone regeneration using hyaluronic acid-based hydrogel with bone morphogenic protein-2 and human mesenchymal stem cells. Biomaterials. 2007;28(10):1830-1837.

18. Patterson J, Siew R, Herring SW, Lin ASP, Guldberg R, Stayton PS. Hyaluronic acid hydrogels with controlled degradation properties for oriented bone regeneration. Biomaterials. 2010;31(26):6772-6781.

19. Lee P, Tran K, Chang W, Shelke NB, Kumbar SG, Yu X. Influence of chondroitin sulfate and hyaluronic acid presence in nanofibers and its alignment on the bone marrow stromal cells: cartilage regeneration. J Biomed Nanotechnol. 2014;10(8):1469-1479.

20. Correia C, Bhumiratana S, Yan L-P, et al. Development of silk-based scaffolds for tissue engineering of bone from human adipose-derived stem cells. Acta Biomater. 2012;8(7):2483-2492.

21. Zhang W, Zhu C, Ye D, et al. Porous silk scaffolds for delivery of growth factors and stem cells to enhance bone regeneration. PloS One. 2014;9(7):e102371.

22. Zhang Y, Fan W, Nothdurft L, et al. In vitro and in vivo evaluation of adenovirus combined silk fibroin scaffolds for bone morphogenetic protein-7 gene delivery. Tissue Eng Part C Methods. 2011;17(8):789-797. 
23. Xin X, Hussain M, Mao JJ. Continuing differentiation of human mesenchymal stem cells and induced chondrogenic and osteogenic lineages in electrospun PLGA nanofiber scaffold. Biomaterials. 2007;28(2):316-325.

24. Park GE, Pattison MA, Park K, Webster TJ. Accelerated chondrocyte functions on NaOH-treated PLGA scaffolds. Biomaterials. 2005;26(16): 3075-3082.

25. Gentile P, Chiono V, Carmagnola I, Hatton PV. An overview of poly(lactic-co-glycolic) acid (PLGA)-based biomaterials for bone tissue engineering. Int J Mol Sci. 2014;15(3):3640-3659.

26. Tamjid E, Bagheri R, Vossoughi M, Simchi A. Effect of TiO2 morphology on in vitro bioactivity of polycaprolactone/TiO2 nanocomposites. Mater Lett. 2011;65(15-16):2530-2533.

27. Tamjid E, Bagheri R, Vossoughi M, Simchi A. Effect of particle size on the in vitro bioactivity, hydrophilicity and mechanical properties of bioactive glass-reinforced polycaprolactone composites. Mater Sci Eng C. 2011;31(7):1526-1533.

28. Kamath MS, Ahmed SSSJ, Dhanasekaran M, Santosh SW. Polycaprolactone scaffold engineered for sustained release of resveratrol: therapeutic enhancement in bone tissue engineering. Int J Nanomedicine. 2014; 9:183-195.

29. Streicher RM, Schmidt M, Fiorito S. Nanosurfaces and nanostructures for artificial orthopedic implants. 2007.

30. Xing ZC, Han SJ, Shin YS, et al. Enhanced osteoblast responses to poly(methyl methacrylate)/hydroxyapatite electrospun nanocomposites for bone tissue engineering. J Biomater Sci Polym Ed. 2013;24(1): 61-76.

31. Jaeblon T. Polymethylmethacrylate: properties and contemporary uses in orthopaedics. J Am Acad Orthop Surg. 2010;18(5):297-305.

32. Lopes MS, Jardini AL, Filho RM. Poly (lactic acid) production for tissue engineering applications. Procedia Eng. 2012;42(0):1402-1413.

33. Ma R, Tang T. Current strategies to improve the bioactivity of PEEK. Int J Mol Sci. 2014;15(4):5426-5445.

34. Evans NT, Torstrick FB, Lee CSD, et al. High-strength, surface-porous polyether-ether-ketone for load-bearing orthopedic implants. Acta Biomater. 2015;13(0):159-167.

35. Xia L, Feng B, Wang P, et al. In vitro and in vivo studies of surfacestructured implants for bone formation. Int J Nanomedicine. 2012;7: 4873.

36. Mishnaevsky Jr L, Levashov E, Valiev RZ, et al. Nanostructured titanium-based materials for medical implants: Modeling and development. Mater Sci Eng R Rep. 2014;81(0):1-19.

37. Webster TJ, Ejiofor JU. Increased osteoblast adhesion on nanophase metals: Ti, Ti6Al4V, and CoCrMo. Biomaterials. 2004;25(19): 4731-4739.

38. Ryu JJ, Shrotriya P. Influence of roughness on surface instability of medical grade cobalt-chromium alloy (CoCrMo) during contact corrosion-fatigue. Appl Surf Sci. 2013;273:536-541.

39. Yamanaka K, Mori M, Chiba A. Nanoarchitectured Co-Cr-Mo orthopedic implant alloys: Nitrogen-enhanced nanostructural evolution and its effect on phase stability. Acta Biomater. 2013;9(4):6259-6267.

40. Zhao L, Wang H, Huo K, et al. Antibacterial nano-structured titania coating incorporated with silver nanoparticles. Biomaterials. 2011;32(24): 5706-5716.

41. Esfandiari N, Simchi A, Bagheri R. Size tuning of Ag-decorated TiO2 nanotube arrays for improved bactericidal capacity of orthopedic implants. J Biomed Mater Res A. 2014;102(8):2625-2635.

42. Pauksch L, Hartmann S, Rohnke M, et al. Biocompatibility of silver nanoparticles and silver ions in primary human mesenchymal stem cells and osteoblasts. Acta Biomater. 2014;10(1):439-449.

43. Krawczynska AT, Gloc M, Lublinska K. Intergranular corrosion resistance of nanostructured austenitic stainless steel. J Mater Sci. 2013; 48(13):4517-4523.

44. Cai Y, Zhang K, Zhang Z, Dong J, Lei Y, Zhang T. Surface nanostructure formations in an AISI 316L stainless steel induced by pulsed electron beam treatment. J Nanomater. 2015;2015:5.

45. Mohandas G, Oskolkov N, McMahon MT, Walczak P, Janowski M. Porous tantalum and tantalum oxide nanoparticles for regenerative medicine. Acta Neurobiol Exp. 2014;74:188-196.
46. Zhou C, Deng C, Chen X, et al. Mechanical and biological properties of the micro-/nano-grain functionally graded hydroxyapatite bioceramics for bone tissue engineering. J Mech Behav Biomed Mater. 2015(0).

47. Bosco R, Iafisco M, Tampieri A, Jansen JA, Leeuwenburgh SCG, van den Beucken JJJP. Hydroxyapatite nanocrystals functionalized with alendronate as bioactive components for bone implant coatings to decrease osteoclastic activity. Appl Surf Sci. 2015;328(0):516-524.

48. Patel KD, El-Fiqi A, Lee H-HH-Y, et al. Chitosan-nanobioactive glass electrophoretic coatings with bone regenerative and drug delivering potential. J Mater Chem. 2012;22(47):24945-24956.

49. Price RL, Haberstroh KM, Webster TJ. Enhanced functions of osteoblasts on nanostructured surfaces of carbon and alumina. Med Biol Eng Comput. 2003;41(3):372-375.

50. Yang L, Zhang L, Webster TJ. Carbon nanostructures for orthopedic medical applications. Nanomedicine. 2011;6(7):1231-1244.

51. Newman P, Minett A, Ellis-Behnke R, Zreiqat H. Carbon nanotubes: their potential and pitfalls for bone tissue regeneration and engineering. Nanomedicine. 2013;9(8):1139-1158.

52. Zhao C, Lu X, Zanden C, Liu J. The promising application of graphene oxide as coating materials in orthopedic implants: preparation, characterization and cell behavior. Biomed Mater. 2015;10(1):015019.

53. Mansoorianfar M, Shokrgozar MA, Mehrjoo M, Tamjid E, Simchi A. Nanodiamonds for surface engineering of orthopedic implants: enhanced biocompatibility in human osteosarcoma cell culture. Diam Relat Mater. 2013;40(0):107-114.

54. Garmendia N, Olalde B, Obieta I. 16 - Biomedical applications of ceramic nanocomposites. In: Banerjee R, Manna I, editors. Ceramic Nanocomposites: Cambridge, UK: Woodhead Publishing; 2013: 530-547.

55. Gain AK, Zhang L, Liu W. Microstructure and material properties of porous hydroxyapatite-zirconia nanocomposites using polymethyl methacrylate powders. Mater Des. 2015;67(0):136-144.

56. Hickey DJ, Ercan B, Sun L, Webster TJ. Adding MgO nanoparticles to hydroxyapatite-PLLA nanocomposites for improved bone tissue engineering applications. Acta Biomater. 2015;14(0):175-184.

57. Liao CZ, Li K, Wong HM, Tong WY, Yeung KWK, Tjong SC. Novel polypropylene biocomposites reinforced with carbon nanotubes and hydroxyapatite nanorods for bone replacements. Mater Sci Eng C. 2013; 33(3):1380-1388.

58. Liu X, Mou Y, Wu S, Man HC. Synthesis of silver-incorporated hydroxyapatite nanocomposites for antimicrobial implant coatings. Appl Surf Sci. 2013;273(0):748-757.

59. Yan Y, Zhang X, Huang Y, Ding Q, Pang X. Antibacterial and bioactivity of silver substituted hydroxyapatite/TiO nanotube composite coatings on titanium. Appl Surf Sci. 2014;314(0):348-357.

60. Pishbin F, Mourino V, Gilchrist JB, et al. Single-step electrochemical deposition of antimicrobial orthopaedic coatings based on a bioactive glass/chitosan/nano-silver composite system. Acta Biomater. 2013;9(7): 7469-7479.

61. Zhou C, Shi Q, Guo W, et al. Electrospun bio-nanocomposite scaffolds for bone tissue engineering by cellulose nanocrystals reinforcing maleic anhydride grafted PLA. ACS Appl Mater interfaces. 2013;5(9):3847-3854.

62. Cheng Y, Ramos D, Lee P, Liang D, Yu X, Kumbar SG. Collagen functionalized bioactive nanofiber matrices for osteogenic differentiation of mesenchymal stem cells: bone tissue engineering. J Biomed Nanotechnol. 2014;10(2):287-298.

63. El-Ghannam A. Bone reconstruction: from bioceramics to tissue engineering. Expert Rev Med Devices. 2005;2(1):87-101.

64. Wu S, Liu X, Yeung KWK, Liu C, Yang X. Biomimetic porous scaffolds for bone tissue engineering. Mater Sci Eng R Rep. 2014;80(0):1-36.

65. Hoexter DL. Bone regeneration graft materials. J Oral Implantol. 2002; 28(6):290-294.

66. Salgado AJ, Oliveira JM, Martins A, et al. Tissue engineering and regenerative medicine: past, present, and future. Int Rev Neurobiol. 2013; 108:1-33.

67. Thibault RA, Mikos AG, Kasper FK. Scaffold/extracellular matrix hybrid constructs for bone-tissue engineering. Adv Healthc Mater. 2013; 2(1):13-24. 
68. Stevens MM. Biomaterials for bone tissue engineering. Mater Today. 2008;11(5):18-25.

69. Laurencin CT, Ambrosio AM, Borden MD, Cooper JA Jr. Tissue engineering: orthopedic applications. Annu Rev Biomed Eng. 1999;1:19-46.

70. Christenson EM, Anseth KS, van den Beucken JJJP, et al. Nanobiomaterial applications in orthopedics. J Orthop Res. 2007;25(1):11-22.

71. Qu D, Mosher CZ, Boushell MK, Lu HH. Engineering complex orthopaedic tissues via strategic biomimicry. Ann Biomed Eng. 2014;3:3.

72. de Guzman RC, Saul JM, Ellenburg MD, et al. Bone regeneration with BMP-2 delivered from keratose scaffolds. Biomaterials. 2013;34(6): 1644-1656.

73. Reddi AH, Cunningham NS. Bone induction by osteogenin and bone morphogenetic proteins. Biomaterials. 1990;11:33-34.

74. Liu C, Wan P, Tan LL, Wang K, Yang K. Preclinical investigation of an innovative magnesium-based bone graft substitute for potential orthopaedic applications. J Orthop Translat. 2014;2(3):139-148.

75. Pompa L, Rahman ZU, Munoz E, Haider W. Surface characterization and cytotoxicity response of biodegradable magnesium alloys. Mater Sci Eng C. 2015;49(0):761-768.

76. Serra G, Morais L, Elias CN, et al. Nanostructured severe plastic deformation processed titanium for orthodontic mini-implants. Mater Sci Eng C. 2013;33(7):4197-4202.

77. Estrin Y, Ivanova EP, Michalska A, Truong VK, Lapovok R, Boyd R. Accelerated stem cell attachment to ultrafine grained titanium. Acta Biomater. 2011;7(2):900-906.

78. Wang CT, Gao N, Gee MG, Wood RJK, Langdon TG. Processing of an ultrafine-grained titanium by high-pressure torsion: an evaluation of the wear properties with and without a TiN coating. J Mech Behav Biomed Mater. 2013;17(0):166-175.

79. Park J-W, Kim Y-J, Park CH, et al. Enhanced osteoblast response to an equal channel angular pressing-processed pure titanium substrate with microrough surface topography. Acta Biomater. 2009;5(8):3272-3280.

80. Perla V, Webster TJ. Better osteoblast adhesion on nanoparticulate selenium - A promising orthopedic implant material. J Biomed Mater Res A. 2005;75(2):356-364.

81. Tran PA, Sarin L, Hurt RH, Webster TJ. Titanium surfaces with adherent selenium nanoclusters as a novel anticancer orthopedic material. J Biomed Mater Res A. 2010;93(4):1417-1428.

82. Tran P, Webster TJ. Enhanced osteoblast adhesion on nanostructured selenium compacts for anti-cancer orthopedic applications. Int J Nanomedicine. 2008;3(3):391.

83. Catledge SA, Fries MD, Vohra YK, et al. Nanostructured ceramics for biomedical implants. J Nanosci Nanotechnol. 2002;2(3-4):293-312.

84. Simchi A, Tamjid E, Pishbin F, Boccaccini A. Recent progress in inorganic and composite coatings with bactericidal capability for orthopaedic applications. Nanomedicine. 2011;7(1):22-39.

85. Ovid'ko I, Sheinerman A. Micromechanisms for improved fracture toughness in nanoceramics. Rev Adv Mater Sci. 2011;29(2):105-125.

86. Hafezi F, Hosseinnejad F, Fooladi A, Mohit Mafi S, Amiri A, Nourani M. Transplantation of nano-bioglass/gelatin scaffold in a non-autogenous setting for bone regeneration in a rabbit ulna. J Mater Sci Mater Med. 2012; 23(11):2783-2792.

87. Agarwal R, García AJ. Biomaterial strategies for engineering implants for enhanced osseointegration and bone repair. Adv Drug Deliv Rev. 2015. Epub 2015 Apr 8.

88. Gallo J, Holinka M, Moucha CS. Antibacterial surface treatment for orthopaedic implants. Int J Mol Sci. 2014;15(8):13849-13880.

89. Park H, Temenoff JS, Mikos AG. Biodegradable orthopedic implants. Engineering of Functional Skeletal Tissues. New York: Springer; 2007: 55-68.

90. Mandal BB, Grinberg A, Seok Gil E, Panilaitis B, Kaplan DL. Highstrength silk protein scaffolds for bone repair. Proc Nat Acad Sci. 2012; 109(20):7699-7704.

91. Sahoo NG, Pan YZ, Li L, He CB. Nanocomposites for bone tissue regeneration. Nanomedicine. 2013;8(4):639-653.

92. Sadat-Shojai M, Khorasani M-T, Jamshidi A. 3-Dimensional cell-laden nano-hydroxyapatite/protein hydrogels for bone regeneration applications. Mater Sci Eng C. 2015;49(0):835-843.
93. Baradaran S, Moghaddam E, Basirun WJ, et al. Mechanical properties and biomedical applications of a nanotube hydroxyapatite-reduced graphene oxide composite. Carbon. 2014;69(0):32-45.

94. Wu M, Wang Q, Liu X, Liu H. Biomimetic synthesis and characterization of carbon nanofiber/hydroxyapatite composite scaffolds. Carbon. 2013;51(0):335-345.

95. Deligianni DD, Katsala N, Ladas S, Sotiropoulou D, Amedee J, Missirlis Y. Effect of surface roughness of the titanium alloy $\mathrm{Ti}-6 \mathrm{Al}-4 \mathrm{~V}$ on human bone marrow cell response and on protein adsorption. Biomaterials. 2001;22(11):1241-1251.

96. Koller G, Cook RJ, Thompson ID, Watson TF, Di Silvio L. Surface modification of titanium implants using bioactive glasses with air abrasion technologies. J Mater Sci Mater Med. 2007;18(12): 2291-2296.

97. Chen W-C, Chen Y-S, Ko C-L, Lin Y, Kuo T-H, Kuo H-N. Interaction of progenitor bone cells with different surface modifications of titanium implant. Mater Sci Eng C. 2014;37(0):305-313.

98. Variola F, Brunski JB, Orsini G, de Oliveira PT, Wazen R, Nanci A. Nanoscale surface modifications of medically relevant metals: stateof-the art and perspectives. Nanoscale. 2011;3(2):335-353.

99. Ciganovic J, Stasic J, Gakovic B, et al. Surface modification of the titanium implant using TEA CO 2 laser pulses in controllable gas atmospheres-Comparative study. Appl Surf Sci. 2012;258(7): 2741-2748.

100. Lorenzetti M, Biglino D, Novak S, Kobe S. Photoinduced properties of nanocrystalline TiO2-anatase coating on Ti-based bone implants. Mater Sci Eng C. 2014;37(0):390-398.

101. Lin L, Wang H, Ni M, et al. Enhanced osteointegration of medical titanium implant with surface modifications in micro/nanoscale structures. J Orthop Translat. 2014;2(1):35-42.

102. Li L-H, Kong Y-M, Kim H-W, et al. Improved biological performance of Ti implants due to surface modification by micro-arc oxidation. Biomaterials. 2004;25(14):2867-2875.

103. Ordikhani F, Tamjid E, Simchi A. Characterization and antibacterial performance of electrodeposited chitosan-vancomycin composite coatings for prevention of implant-associated infections. Mater Sci Eng C. 2014;41(0):240-248.

104. Rosales-Leal JI, Rodríguez-Valverde MA, Mazzaglia G, et al. Effect of roughness, wettability and morphology of engineered titanium surfaces on osteoblast-like cell adhesion. Colloids Surf A Physicochem Eng Asp. 2010;365(1-3):222-229.

105. Wu S, Liu X, Yeung KW, et al. Surface nano-architectures and their effects on the mechanical properties and corrosion behavior of Ti-based orthopedic implants. Surf Coat Technol. 2013;233:13-26.

106. Prodana M, Duta M, Ionita D, et al. A new complex ceramic coating with carbon nanotubes, hydroxyapatite and $\mathrm{TiO} 2$ nanotubes on $\mathrm{Ti}$ surface for biomedical applications. Ceram Int. 2015;41(5, Part A): 6318-6325.

107. Salou L, Hoornaert A, Louarn G, Layrolle P. Enhanced osseointegration of titanium implants with nanostructured surfaces: an experimental study in rabbits. Acta Biomater. 2015;11(0):494-502.

108. ProdanovL, LamersE, Domanski M, Luttge R, Jansen JA, Walboomers XF. The effect of nanometric surface texture on bone contact to titanium implants in rabbit tibia. Biomaterials. 2013;34(12):2920-2927.

109. Safonov V, Zykova A, Smolik J, Rogowska R, Lukyanchenko V, Kolesnikov D. Modification of implant material surface properties by means of oxide nano-structured coatings deposition. Appl Surf Sci. 2014;310(0):174-179.

110. Park SW, Lee D, Lee HR, et al. Generation of functionalized polymer nanolayer on implant surface via initiated chemical vapor deposition (iCVD). J Colloid Interface Sci. 2015;439(0):34-41.

111. Ordikhani F, Simchi A. Long-term antibiotic delivery by chitosanbased composite coatings with bone regenerative potential. Appl Surf Sci. 2014;317(0):56-66.

112. Ahmed RA, Fekry AM, Farghali RA. A study of calcium carbonate/multiwalled-carbon nanotubes/chitosan composite coatings on Ti-6Al-4V alloy for orthopedic implants. Appl Surf Sci. 2013;285, Part B(0): 309-316. 
113. Ordikhani F, Ramezani Farani M, Dehghani M, Tamjid E, Simchi A. Physicochemical and biological properties of electrodeposited graphene oxide/chitosan films with drug-eluting capacity. Carbon. 2015;84(0):91-102.

114. Nguyen HQ, Deporter DA, Pilliar RM, Valiquette N, Yakubovich R. The effect of sol-gel-formed calcium phosphate coatings on bone ingrowth and osteoconductivity of porous-surfaced $\mathrm{Ti}$ alloy implants. Biomaterials. 2004;25(5):865-876.

115. Shim IK, Chung HJ, Jung MR, et al. Biofunctional porous anodized titanium implants for enhanced bone regeneration. J Biomed Mater Res A. 2014;102(10):3639-3648.

116. Ordikhani F, Tamjid E, Simchi A. Characterization and antibacterial performance of electrodeposited chitosan-vancomycin composite coatings for prevention of implant associated infections. Mater Sci Eng C. 2014(41):240-248.

117. Radin S, Ducheyne P. Controlled release of vancomycin from thin sol-gel films on titanium alloy fracture plate material. Biomaterials. 2007;28(9):1721-1729.

118. Mattioli-Belmonte M, Cometa S, Ferretti C, et al. Characterization and cytocompatibility of an antibiotic/chitosan/cyclodextrins nanocoating on titanium implants. Carbohydr Polym. 2014;110(0):173-182.

119. Chennell P, Feschet-Chassot E, Devers T, Awitor KO, Descamps S, Sautou V. In vitro evaluation of $\mathrm{TiO}_{2}$ nanotubes as cefuroxime carriers on orthopaedic implants for the prevention of periprosthetic joint infections. Int J Pharm. 2013;455(1-2):298-305.

120. Yun YH, Eteshola E, Bhattacharya A, et al. Tiny medicine: nanomaterialbased biosensors. Sensors (Basel). 2009;9(11):9275-9299.

121. Yang L, Webster T. Monitoring tissue healing through nanosensors. In: Webster TJ, editor. Nanotechnology Enabled In Situ Sensors for Monitoring Health. New York: Springer; 2011:41-59.

122. Lin Y, Taylor S, Li H, et al. Advances toward bioapplications of carbon nanotubes. J Mater Chem. 2004;14(4):527-541.

123. Supronowicz PR, Ajayan PM, Ullmann KR, Arulanandam BP, Metzger DW, Bizios R. Novel current-conducting composite substrates for exposing osteoblasts to alternating current stimulation. J Biomed Mater Res. 2002;59(3):499-506.

124. Sirinrath S, Thomas JW. Multiwalled carbon nanotubes enhance electrochemical properties of titanium to determine in situ bone formation. Nanotechnology. 2008;19(29):295101.

125. Yun Y, Bange A, Heineman WR, et al. A nanotube array immunosensor for direct electrochemical detection of antigen-antibody binding. Sens Actuators B Chem. 2007;123(1):177-182.

126. Jiang L, Gao L. Fabrication and characterization of carbon nanotubetitanium nitride composites with enhanced electrical and electrochemical properties. J Am Ceram Soc. 2006;89(1):156-161.

127. Bull E, Madani SY, Sheth R, Seifalian A, Green M, Seifalian AM. Stem cell tracking using iron oxide nanoparticles. Int J Nanomedicine. 2014;9:1641-1653

128. Wimpenny I, Markides H, El Haj AJ. Orthopaedic applications of nanoparticle-based stem cell therapies. Stem Cell Res Ther. 2012; 3(2): 13 .

129. Hsieh MF, Li JK, Lin CA, et al. Tracking of cellular uptake of hydrophilic CdSe/ZnS quantum dots/hydroxyapatite composites nanoparticles in MC3T3-E1 osteoblast cells. J Nanosci Nanotechnol. 2009; 9(4):2758-2762.

130. Xi D, Dong S, Meng X, Lu Q, Meng L, Ye J. Gold nanoparticles as computerized tomography (CT) contrast agents. RSC Adv. 2012;2(33):12515-12524.

131. Popovtzer R, Agrawal A, Kotov NA, et al. Targeted gold nanoparticles enable molecular CT imaging of cancer. Nano Lett. 2008;8(12): 4593-4596.

132. Ahn S, Jung S, Lee S. Gold nanoparticle contrast agents in advanced X-ray imaging technologies. Molecules. 2013;18(5):5858-5890.

133. Ganesh N, Ashokan A, Rajeshkannan R, Chennazhi K, Koyakutty M, Nair SV. Magnetic resonance functional nano-hydroxyapatite incorporated poly(caprolactone) composite scaffolds for in situ monitoring of bone tissue regeneration by MRI. Tissue Eng A. 2014;20(19-20): 2783-2794
134. Potapova I. Functional imaging in diagnostic of orthopedic implantassociated infections. Diagnostics. 2013;3(4):356.

135. Ruther C, Lohrengel A, Kluess D, et al. Current Possibilities for Detection of Loosening of Total Hip Replacements and How Intelligent Implants Could Improve Diagnostic Accuracy. Rijeka, Croatia: INTECH Open Access Publisher; 2012.

136. Gou P, Kraut ND, Feigel IM, et al. Carbon nanotube chemiresistor for wireless pH sensing. Sci Rep. 2014;4:4468.

137. Kansara M, Thomas DM. Molecular pathogenesis of osteosarcoma. DNA Cell Biol. 2007;26(1):1-18.

138. Suva LJ, Washam C, Nicholas RW, Griffin RJ. Bone metastasis: mechanisms and therapeutic opportunities. Nat Rev Endocrinol. 2011; 7(4):208-218.

139. Mohamed M, Borchard G, Jordan O. In situ forming implants for local chemotherapy and hyperthermia of bone tumors. J Drug Deliv Sci Technol. 2012;22:393-408.

140. Li B, Jia D, Zhou Y, Hu Q, Cai W. In situ hybridization to chitosan/ magnetite nanocomposite induced by the magnetic field. J Magn Magn Mater. 2006;306(2):223-227.

141. Hu Q, Chen F, Li B, Shen J. Preparation of three-dimensional nanomagnetite/chitosan rod. Mater Lett. 2006;60(3):368-370.

142. Murakami S, Hosono T, Jeyadevan B, Kamitakahara M, Ioku K. Hydrothermal synthesis of magnetite/hydroxyapatite composite material for hyperthermia therapy for bone cancer. J Ceram Soc Jpn. 2008; 116(1357):950-954.

143. Thomas K, Sayre P. Research strategies for safety evaluation of nanomaterials, part I: evaluating the human health implications of exposure to nanoscale materials. Toxicol Sci. 2005;87(2):316-321.

144. Oberdorster G, Oberdorster E, Oberdorster J. Nanotoxicology: an emerging discipline evolving from studies of ultrafine particles. Environ Health Perspect. 2005;113(7):823-839.

145. Majestic BJ, Erdakos GB, Lewandowski M, et al. A review of selected engineered nanoparticles in the atmosphere: sources, transformations, and techniques for sampling and analysis. Int J Occup Environ Health . 2010;16(4):488-507.

146. Madl AK, Kovochich M, Liong M, Finley BL, Paustenbach DJ, Oberdörster G. Toxicology of wear particles of cobalt-chromium alloy metal-on-metal hip implants Part II: Importance of physicochemical properties and dose in animal and in vitro studies as a basis for risk assessment. Nanomedicine. 2015;11(5):1285-1298.

147. Webster TJ, Ahn ES. Nanostructured biomaterials for tissue engineering bone. Adv Biochem Eng Biotechnol. 2007;103:275-308.

148. Cheng L-C, Jiang X, Wang J, Chen C, Liu R-S. Nano-bio effects: interaction of nanomaterials with cells. Nanoscale. 2013;5(9):3547-3569.

149. Li X, Wang L, Fan Y, Feng Q, Cui F-Z. Biocompatibility and toxicity of nanoparticles and nanotubes. J Nanomater. 2012;2012:19.

150. Bakand S, Hayes A, Dechsakulthorn F. Nanoparticles: a review of particle toxicology following inhalation exposure. Inhal Toxicol. 2012; 24(2):125-135.

151. Fan AM, Alexeeff G. Nanotechnology and nanomaterials: toxicology, risk assessment, and regulations. J Nanosci Nanotechnol. 2010;10(12): 8646-8657.

152. Fischer HC, Chan WC. Nanotoxicity: the growing need for in vivo study. Curr Opin Biotechnol. 2007;18(6):565-571.

153. Webster TJ. Nanomedicine: real commercial potential or just hype? Int J Nanomedicine. 2006;1(4):373-374.

154. Morigi V, Tocchio A, Bellavite Pellegrini C, Sakamoto JH, Arnone M, Tasciotti E. Nanotechnology in medicine: from inception to market domination. J Drug Deliv. 2012;2012:7. 


\section{Publish your work in this journal}

The International Journal of Nanomedicine is an international, peerreviewed journal focusing on the application of nanotechnology in diagnostics, therapeutics, and drug delivery systems throughout the biomedical field. This journal is indexed on PubMed Central, MedLine, CAS, SciSearch $\AA$, Current Contents $\AA /$ Clinical Medicine,

Journal Citation Reports/Science Edition, EMBase, Scopus and the Elsevier Bibliographic databases. The manuscript management system is completely online and includes a very quick and fair peer-review system, which is all easy to use. Visit http://www.dovepress.com/ testimonials.php to read real quotes from published authors.

Submit your manuscript here: http://www.dovepress.com/international-journal-of-nanomedicine-journal 